PRZEGLĄD NAUK HISTORYCZNYCH 2020, R. XIX, NR 2

https://doi.org/10.18778/1644-857X.19.02.11

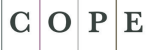

Member since 2018

\title{
Rodzice legalizujący dzieci w świetle akt Sądu Pokoju Okręgu Radomszczańskiego w latach 1845-1874
}

Streszczenie. Protokoły legalizacji powstałe w Sądzie Pokoju Okręgu Radomszczańskiego w latach 1845-1874 pozwoliły na przeprowadzenie analiz dotyczacych osób decydujących się na ten akt prawny. Na podstawie 43 dokumentów ustalono 49 osób legalizujących swoje dzieci. Stanowiło je 41 matek i ośmiu ojców. W sześciu przypadkach legalizowały pary, w dwóch tylko ojcowie, w 35 matki. Matki znajdowały się w różnym stanie cywilnym. Wśród nich 11 było pannami, 16 mężatkami, a 14 wdowami. Najczęściej były to zatem matki niebędące w związku małżeńskim. Ustalono jeden przypadek legalizacji dziecka poczętego $z$ niemężem w czasie trwania związku małżeńskiego.

Ustalono wiek 40 rodziców uznających dzieci. Legalizujący mieli od 20 do 61 lat. Spośród 41 matek wiek znany jest dla $37 \mathrm{z}$ nich. Sa to kobiety w wieku od 25 do 61 lat (przeciętnie liczyły 48,7 lat). Dominują matki w średnim wieku, liczące 37-59 lat, których było 33 (89,2\%). Wynikało to $z$ faktu, że decydowały się na legalizację dziecka dopiero, gdy osiągnęło ono dojrzałość. Na ogółem 49 legalizujących większość (47), tj. 95,9\%, stanowią katolicy, ponadto wystąpiła jedna Żydówka i jedna ewangeliczka.

Spośród legalizujących stan społeczny ustalono dla 25 matek i czterech ojców. W większości (20), tj. 80\%, były to kobiety wywodzace się z niższych warstw społeczeństwa bąd́ je stanowiące. Kobiety pochodzenia chłopskiego (sześć) były określane jako pracowita, włościanka, córka rataja, rolnika, gospodarza. Wystapiły ponadto kobiety pracujące jako wyrobnice (11) oraz służące (trzy). Legalizującymi byli w większości mieszkańcy wsi (47), tj. 95,9\%, tylko dwie legalizujące pochodziły $z$ miasta.

Większość legalizujących dzieci stanowiły przede wszystkim matki w średnim wieku, pochodzące $z$ niższych warstw społecznych mieszkających na wsi.

Słowa kluczowe: legalizacje dzieci, dzieci nieślubne, służba wojskowa, sąd pokoju, okręg radomszczański, XIX wiek.

* Wydział Filozoficzno-Historyczny, Instytutu Historii, Katedra Historii Historiografii i Nauk Pomocniczych Historii, e-mail: piotr.szkutnik@uni.lodz.pl 


\section{Wstęp}

$\mathrm{L}$

egalizacji określanej jako uznanie/przyznanie dziecka dokonywali rodzice, którzy $z$ różnych względów nie byli obecni $\mathrm{w}$ trakcie spisywania aktu urodzenia. W większości legalizowane dzieci były urodzone w związkach pozamałżeńskich ${ }^{1}$, czyli stanowiły naturalne potomstwo ${ }^{2}$. Akt uznania dziecka umożliwiały kodeksy Napoleona z 1808 r. oraz Cywilny Królestwa Polskiego $z 1825 \mathrm{r}^{3}$ Poczatkowo nie było sprecyzowane, jaki urząd ma rejestrować taka dokumentację. Postanowienie Komisji Rządowej Sprawiedliwości z 1842 r. poleciło przyjmować tego typu oświadczenia przez sądy pokoju w danym okręgu.

Analizowane zapisy zostały zarejestrowane w Sązie Pokoju Okręgu Radomszczańskiego w latach 1845-18744. Stanowia je łacznie 43 protokoły. Dokumenty te zawierały podstawowe informacje o osobach składajacych tego typu akty woli. Były to dane

${ }^{1}$ M. Teleszewska, Status prawny dzieci nieślubnych na ziemiach polskich $w$ dobie zaborów $w$ świetle Kodeksu Cywilnego Napoleona, „Czasopismo Prawno-Historyczne” 2014, t. LXVI, z. 1, s. 383-391; P. Szku tnik, Owoce nieformalnych zwiazków. Egzemplifikacje na podstawie akt stanu cywilnego parafii Szadek z początku XIX w., [w:] Antropologia miłości, t. VI (Miłość sprzedajna), red. B. Płonka-Syroka, K. Marchel, A. Syroka, Wrocław 2014, s. 193-203.

2 Artykuł stanowi kontynuację rozważań zamieszczonych w publikacji: P. Szkutnik, Legalizacje dzieci $w$ świetle akt Sadu Pokoju Okręgu Radomszczańskiego w latach 1845-1874, „Przeszłość Demograficzna Polski” 2019, t. XL, s. $197-214$.

${ }^{3}$ Kodex Napoleona z przypisami. Xiag trzy, Warszawa 1810, s. 89-91; D. D zi erożyński, Instrukcya dokładna o urzędnikach $i$ aktach stanu cywilnego, Warszawa 1813, s. 84-85; Dziennik Praw Królestwa Polskiego, t. X, Warszawa 1825, s. 155-162; Prawo cywilne obowiazujące $w$ Królestwie Polskim, t. I, wyd. S. Zawadzki, Warszawa 1860, s. 207-212.

${ }^{4} \mathrm{~W}$ celu poprawnej identyfikacji geograficznej przez współczesnego odbiorcę występująca w artykule nazwę okręgu sądowego przyjęto za: M. Bandurka, Zmiany administracyjne i terytorialne ziem województwa łódzkiego w XIX i XX wieku, Łódź 1995, s. 32-33, jednak w źródłach w latach 1845-1867 nazwa instytucji brzmiała: Sąd Pokoju Okręgu Radomskiego. Por. Archiwum Państwowe w Piotrkowie Trybunalskim [dalej: APPT], Sąd Pokoju Okręgu Radomszczańskiego [dalej: SPOR], sygn. 42. Następnie sądy pokoju określane od nazwy okręgów, od $1867 \mathrm{r}$. nazywano od miejscowości, gdzie odbywały się posiedzenia. Por. M. Bandurka, op. cit., s. 59-60. W 1867 r. ze względu na nieporozumienia dotyczące nazewnictwa identycznego $z$ powiatem radomskim w guberni radomskiej nazwę miasta "Radomsko” zmieniono na „Noworadomsko” (ibidem, s. 199). Stąd następnie funkcjonowała nazwa: Sad Pokoju w Noworadomsku. Por. APPT, SPOR, sygn. 42. W latach 1845-1874 omawiany sąd znajdował się w granicach guberni warszawskiej, a od 1867 r. w piotrkowskiej. Por. M. Bandurka, op. cit., s. 30, 64. 
personalne: imię, nazwisko, wiek, miejsce zamieszkania, zawód/ sposób utrzymania, stan cywilny, wyznanie (w przypadku niekatolików), ewentualnie dane współmałżonka. Załączone do protokołów uznania dziecka metryki dodatkowo określają stan społeczny rodziców, choć jeśli nie wszyto ich odpisu obok protokołów, autor starał się uzupełnić tę informację na podstawie oryginałów aktu stanu cywilnego. Wspomniane dane pozwoliły scharakteryzować grupę mieszkańców ówczesnego Królestwa Polskiego, która zdecydowała się na legalizację dzieci.

\section{Stan cywilny i płeć rodziców}

W analizowanych protokołach łącznie 49 osób dokonało legalizacji. W tej liczbie 37 razy wystapił jeden $z$ rodziców (35 matek i dwóch ojców) oraz sześć par. Osobą najczęściej zabiegająca o legalizację dziecka naturalnego była matka. Jako nieobecna przy rejestracji aktu urodzenia potomka nie mogła osobiście uznać go za córkę/ syna, zatem czyniła to aktem uznania.

Jak wspomniano, w 35 przypadkach matka dziecka występowała do sądu $z$ prośba o legalizację potomka. Spośród tych aktów uznania w jednym przypadku matka złożyła oświadczenie w obecności dwóch świadków, w siedmiu pozostałych występuje $z$ mężem (niebędącym ojcem dziecka i go nielegalizujaccym), w pozostałych 27 występuje indywidualnie. W kolejnych sześciu legalizuje dziecko wspólnie $z$ jego ojcem. Łącznie zatem było 41 matek składajacych oświadczenie w protokołach.

Wymienione 41 matek występujących o uznanie dziecka znajdowało się w różnym stanie cywilnym. Wśród nich 11 było pannami, 16 mężatkami, a 14 wdowami (por. wykres 1). Proporcje te dowodzą, że kobiety częściej decydowały się na legalizację, nie będąc $\mathrm{w}$ związu małżeńskim. Wynikało to zapewne $z$ art. 301 Kodeksu Cywilnego Królestwa Polskiego z 1825 r., stanowiącego, że uznanie dziecka naturalnego, niespłodzonego ze współmałżonkiem nie może szkodzić temuż współmałżonkowi ani dzieciom zrodzonym w tym małżeństwie. Mogło się też to wiązać z potencjalnym oporem małżonka przed legalizacją dziecka, szczególnie w przypadku, gdy nie był jego ojcem. Przede wszystkim jednak panny i wdowy, występując przed urzędem, nie potrzebowały asystencji mężczyzn ${ }^{5}$.

5 J. Machut-Kowalczyk, Panny, mężatki i wdowy przed sadem pokoju: prawo a praktyka $w$ Królestwie Polskim na przykładzie akt sąów pokoju okręgu 
Znane $z$ protokołów legalizacji kobiety zachodziły w ciążę jako wdowy lub panny, ale tylko jedna jako mężatka $z$ innym niż mąż mężczyzną.

Stan cywilny/płeć

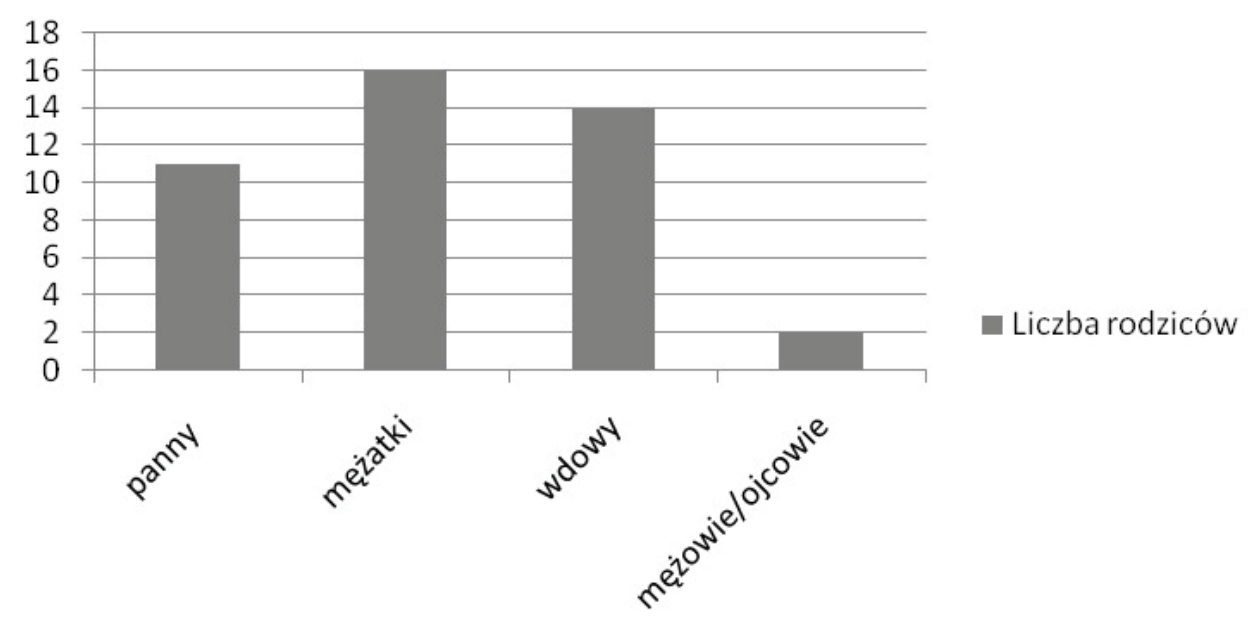

Źródło: Opracowanie własne na podstawie: Archiwum Państwowe w Piotrkowie Trybunalskim, Sąd Pokoju Okręgu Radomszczańskiego, sygn. 42.

\section{Panny}

Wspomniane 11 matek, które były pannami, samodzielnie legalizowały swe naturalne dzieci. Spośród nich tylko jedna podała nazwisko ojca potomka. Łucja Dyasówna 2 kwietnia 1849 r. ${ }^{6}$ zeznała, że będąc panna, w 1823 r. weszła w bardzo bliskie stosunki ze Stefanem Stajnikiem i w ich wyniku 2 marca 1824 r. urodziła syna Kazimierza Dyasa. Kochanek ów, Stefan Stajnik, pochodzący z tej samej wsi co jego partnerka, w momencie legalizacji dziecka już nie żył, zatem nie mógł potwierdzić tych informacji. Łucja Dyasówna

Łęczyckiego, zgierskiego i łódzkiego, „Studia z Dziejów Państwa i Prawa Polskiego” 2013, t. XVI, s. 213.

${ }^{6}$ Daty podano według kalendarza gregoriańskiego. 
nie wyszła za mąż i nie miała innych dzieci ${ }^{7}$ Wśród 43 legalizacji jest to jedyny przypadek ujawnienia danych naturalnego ojca, który nie został później mężem matki dziecka.

Pozostałe kobiety ukryły nazwiska konkubentów. Dość ogólnie opisywały okoliczności, w wyniku których poczęły swe dzieci. Marianna Knayska 29 maja 1849 r. zeznała, że urodziła się w państwie pruskim i $z$ rodzicami w 1824 r. sprowadziła się na ziemie Królestwa Polskiego. W nowym miejscu zamieszkania poznała i weszła „W nader bliskie stosunki $z$ młodemi, a $z$ nazwiska $i$ imienia niepamiętnemi mi osobami”. W wyniku tych związków 31 marca 1829 r. urodziła syna Franciszka ${ }^{8}$. Ludwika Popiołek 28 sierpnia 1868 zeznała, że „będąc w stanie panieńskim w związkach bezślubnych z mężczyzną niezamężnym (sic!), zaszedłszy ciążą, porodziłam" 18 kwietnia 1847 r. syna - Wojciecha Popiołka9 .

\section{Mężatki}

Spośród 16 mężatek, które wystąiły o legalizację dziecka naturalnego, dziewięć zabiegało o uznanie potomka niepochodzacego od aktualnego męża, a pozostałe siedem przypadków dotyczyło obecnego małżonka. Wśród tych pierwszych większość (siedem) stanowiły żony występujące w asystencji mężów, a jedynie dwie samodzielnie.

Wśród żon, które stanęły przed sądem w asystencji mężów niebędacymi ojcami, zdarzył sie jedyny w analizowanej grupie przypadek wystąpienia Żydów. Ryfka Mamelka 7 września 1866 r. w asystencji męża Berka Adlera legalizowała syna Lewka Kidera Mamelkę, którego urodziła jako panna 1 września 1845 r. Lewek Kider nie został uznany za syna podczas ślubu R. Mamelki z B. Adlerem, „bo $z$ kim innym był spłodzony”. Podczas legalizacji B. Adler oświadczył, „że przeciw uznaniu za swego syna przez żonę jego uczynionemu nie ma nic do nadmienienia". W ten sposób w protokole opisywano stosunek mężów będących ojczymami uznawanych synów do legalizacji dokonywanych przez swe żony. Można go określić jako neutralny oraz akceptujący decyzję żon.

\footnotetext{
7 APPT, SPOR, sygn. 42, k. 4-5.

8 Ibidem, k. 7-8.

9 Ibidem, k. 31-31v.
} 
W dwóch przypadkach, jak wspomniano, mężatka wystapiła sama, bez asystencji męża (niebędącego ojcem). Była to m.in. Józefa $z$ Tańskich, która jako wdowa po Pawle Brulikowskim urodziła 26 lipca 1826 r. syna Antoniego Brulikowskiego. Potem ponownie wyszła za mąz - za Antoniego Świerczyńskiego (którego żoną była w momencie legalizacji syna 25 lipca 1848 r.) i nadal wychowywała swojego potomka. Jej aktualny małżonek co prawda nie wystapił przy legalizacji, jednak - jak zeznała jego matka - uważał jej syna za swojego pasierba ${ }^{10}$.

Według Kodeksu Cywilnego Królestwa Polskiego z 1825 r. żona nie mogła zeznawać przed sądem bez upoważnienia męża ${ }^{11}$. Stąd też $\mathrm{w}$ większości przypadków mężowie asystowali żonom. Wspomniane dwie mężatki zapewne posiadały upoważnienie męża do samodzielnego stawiennictwa, co tłumaczyłoby nieobecność małżonka w sadzie ${ }^{12}$.

W grupie siedmiu mężatek $z$ mężami-ojcami podobnie większość, tj. sześć, wystapiła $z$ mężami, a tylko jedna sama. Do tego typu legalizacji dochodziło w sytuacji, gdy rodzice dziecka zawarli związek małżeński po jego narodzinach, przy czym - jak wspominali $\mathrm{w}$ oświadczeniu $-z$ powodu nieznajomości prawa nie zalegalizowali swego naturalnego potomka w akcie ślubu. W takiej sytuacji $\mathrm{dzieci}, \mathrm{tj}$. w tej grupie synowie, byli uznawani za własnych i otrzymywali nazwiska swych ojców.

\section{Wdowy}

W przypadku 14 wdów większość, tj. 10, dokonało aktu uznania dziecka naturalnego, które nie pochodziło ze związku $z$ mężem, a $z$ romansu $z$ innym, nieznanym (nieujawnianym) mężczyzną - niebędącym krewnym i nieżonatym, co było wyrażone niemal w każdej deklaracji matki (choć nie musiało to być zgodne $z$ prawda), by ustrzec się konsekwencji prawnych dla dzieci zrodzonych ze związku kazirodczego lub też w wyniku zdrady małżeńskiej.

W większości (7 na 10) były to kobiety, które urodziły dzieci przed małżeństwem $z$ późniejszym ojczymem dziecka. Wśród nich Rozalia $z$ Lewandowskich, wdowa po Kantym Chobocie, włościan-

\footnotetext{
${ }_{10}$ Ibidem, k. 1-2.

11 Prawo cywilne..., s. 184.

12 J. Machut-Kowalczyk, op. cit., s. 205.
} 
ka, zamieszkała we wsi Wola Wiewiecka w gminie Zamość 5 sierpnia 1867 r., zeznała, że jako panna powiła 5 stycznia 1846 r. syna - Pawła Lewandowskiego ${ }^{13}$.

Dwie kobiety urodziły dzieci po śmierci męża. Wśród nich znalazła się Anastazja Rybakówna, która jako panna licząca 25 lat, w Bęczkowicach 21 lutego 1841 r. poślubiła Wojciecha Borczucha, wdowca zagrodnika, liczącego 42 lata $^{14}$. Wojciech Borczuch zmarł 18 lutego $1844 \mathrm{r}^{15}$ Anastazja nie miała potomstwa ze swym mężem. Kilka lat po jego śmierci, jako wdowa, służyła jako dziewka we dworze we wsi Cieśle, gdzie zaszła w ciążę z nieżonatym mężczyzną i urodziła 27 marca 1850 r. syna Wojciecha. Dziecko do zarejestrowania przez urzędnika stanu cywilnego przyniosła licząca 40 lat akuszerka Marianna Kasprzyk, zamieszkała w Cieślach, w obecności liczącego 50 lat Wojciecha Borczucha, gospodarza $\mathrm{w}$ tejże $\mathrm{wsi}^{16}$. Anastazja, jako liczaca 55 lat wdowa, utrzymujaca się $z$ wyrobku i zamieszkała we wsi Krzętów w gminie Maluszyn, uznała je za syna 27 sierpnia 1870 r. ${ }^{17}$

Jedynie w jednym przypadku wdowa urodziła dziecko spłodzone $z$ innym (trzecim) mężczyzną między kolejnymi związkami. Była to Katarzyna $z$ Nowińskich $1^{\circ}$ voto Żyła, $2^{\circ}$ voto Faska. Po śmierci pierwszego męża Andrzeja Żyły 17 lipca 1848 r., jako wdowa, urodziła 22 czerwca 1851 r. syna Piotra Żyłę vel Nowińskiego. Potem, 15 lutego 1852 r., poślubiła Józefa Faskę, po którego śmierci zalegalizowała 6 października 1872 r. wspomnianego potomka ${ }^{18}$.

Pozostałe cztery wdowy uznawały dzieci będące owocem związku ze zmarłym mężem. Wśród nich znalazła się córka rolnika ${ }^{19}$ Agnieszka $z$ Tkaczyków Borowiecka, wdowa ${ }^{20}$ po Janie Borowieckim, zamieszkała we wsi Borowiecko w gminie Dobryszyce. Franciszek, syn Agnieszki, urodził się 29 marca 1846 r., cztery lata po

13 APPT, SPOR, sygn. 42, k. 20.

${ }^{14}$ Archiwum Państwowe w Łodzi [dalej: APŁ], Urzą Stanu Cywilnego [dalej: USC] Bęczkowice, sygn. 37, Akt ślubu nr 8 z 1841 r.

15 APŁ, USC Bęczkowice, sygn. 40, Akt zgonu nr 15 z 1844 r.

${ }^{16}$ Zdumiewajacym zbiegiem okoliczności jest zbliżony rok urodzenia oraz imię i nazwisko świadka aktu i zmarłego męża Anastazji.

17 APPT, SPOR, sygn. 42, karty bez paginacji.

18 Ibidem.

19 Archiwum Archidiecezji Częstochowskiej [dalej: AACz], Księgi metrykalne, sygn. KM 4493, Akt urodzenia nr 8 z 1823 r.

20 Zawarli małżeństwo 24 I 1841 r. w Dobryszycach. Jan Borowiecki był wówczas służącym. Por. APŁ, USC Dobryszyce, sygn. 10, Akt ślubu nr 3 z 1841 r. 
wcieleniu jej męża do wojska. Matka, wyjaśniając jego pochodzenie, przedstawiła przed sądem 11 października 1867 r. szersze zeznania, zawarte również we wciagniętym do akt oświadczeniu złożonym przed wójtem gminy Dobryszyce ${ }^{21}$ : „Mąż mój Jan Borowiecki w roku 1842 powołany został do wojsk cesarsko-rosyjskich. W pare lat po wzięciu jego do wojska, o ile sobie przypominam w roku 1845 , odebrałam list od męża swego i ja $z$ swem bratem Szymonem byliśmy dwa razy u mojego męża. Raz w mieście Ujeździe, a drugi raz w Radomiu, gdzie $z$ mężem mojem zostałam w ciąży, a w parę miesięcy po powrocie do domu urodziełam syna, któremu nadano na chrzcie świętym imię Franciszek. I już od czasu tego o mężu mojem żadnej wiadomości nie miałam, aż dopiero w roku 1862 powrócił $z$ wojska. Syna Franciszka za własnego uznał, lecz przez niedbalstwo aktu urodzenia nie ulegalizował, a tym więcej, że zaraz po powrocie $z$ wojska życie zakończył"22.

Ponieważ ani matka, będąc chora, ani ojciec przebywający w wojsku nie uczestniczyli przy spisywaniu aktu urodzenia w $1846 \mathrm{r}$., dziecko musiało zostać zalegalizowane aktem sądowym „przyznania”. Jan Borowiecki był synem gajowego w lasach królewskich ${ }^{23}$. Po powrocie $z$ wojska był wyrobnikiem ${ }^{24}$, a zmarł, jako dymisjonowany żołnierz, dopiero 27 grudnia 1865 r., tj. dwa lata przed legalizacja jego syna przez matkę ${ }^{25}$.

Kolejna $z$ wdów, Małgorzata $z$ Kowalczyńskich Fagowska była żoną Norberta Fagowskiego, który po czterech latach od wcielenia do wojska rosyjskiego przybył na trzymiesięczny urlop, w czasie którego ta zaszła w ciążę. Wrócił potem do wojska, gdzie zmarł w 1855 r. Syn małżonków Franciszek urodził się 14 sierpnia 1851 r., przy czym rodzice nie byli obecni przy spisywaniu aktu jego urodzenia. Stąd też matka 6 czerwca 1872 r. „przyznała” go za własnego syna $z$ żądaniem, by nosił nazwisko ojca - Fagowski ${ }^{26}$.

Tekla $z$ Drużyckich $1^{\circ}$ voto Mirecka, $2^{\circ}$ voto Lewińska, w odróżnieniu od poprzednich wdów (które za własne uznawały dzieci urodzone $\mathrm{w}$ trakcie związku małżeńskiego $\mathrm{z}$ ojcem), legalizowała dziecko zrodzone przed ślubem $z$ jego ojcem. Jednocześnie jest to

\footnotetext{
${ }^{21}$ APPT, SPOR, sygn. 42, k. 28.

${ }^{22}$ Ibidem, k. 27.

${ }^{23} \mathrm{AACz}$, Księgi Metrykalne, sygn. KM 1319, Akt urodzenia nr 26 z $1821 \mathrm{r}$.

${ }^{24}$ APE, USC Dobryszyce, sygn. 33, Akt urodzenia nr 32 z 1864 r.

25 APE, USC Dobryszyce, sygn. 34, Akt zgonu nr 55 z 1865 r.

${ }^{26}$ APPT, SPOR, sygn. 42, karty bez paginacji.
} 
jedyny przypadek legalizacji dziecka urodzonego w trakcie małżeństwa i poczętego nie $z$ mężem. Tekla, jako wdowa po pierwszym mężu Aleksandrze Mireckim ${ }^{27}$, zmarłym w Łowiczu 2 lutego 1855 r., weszła w bliskie stosunki $z$ Janem Lewińskim, w wyniku których urodziła 5 lutego 1853 r. Kazimierza Drużyckiego vel Mireckiego. Rodzice Kazimierza nie byli obecni przy spisywaniu jego aktu urodzenia, jednak zalegalizowali syna podczas aktu ślubu 15 kwietnia $1856 \mathrm{r}^{28}$ Mimo to administracja wojskowa zażądała od matki dodatkowego uznania dziecka przed sądem, którego dokonała 26 czerwca 1874 r. ${ }^{29}$

\section{Ojcowie}

Ostatnia grupę stanowią legalizacje dokonane przez ojców dziecka naturalnego, których łącznie było ośmiu. Wspólnie $z$ matką uznawało sześciu ojców, a samodzielnie zaledwie dwóch. Legalizacje były przeprowadzone po zawarciu małżeństwa tegoż ojca $z$ matka nieślubnego dziecka. Dziecko noszace nazwisko panieńskie matki otrzymywało wówczas nazwisko ojca. Ojcem legalizującym dziecko był np. Tadeusz Rybkowski, ogrodnik zamieszkały we wsi Sokola Góra, który 26 września 1849 r. zeznał, że w 1828 r. będąc kawalerem, mieszkajac we wsi Morawinie w parafii Stanowiska, poznał swoją obecną żonę Barbarę, zamieszkałą w Biestrzykowie Wielkim w parafii Rzejowice. Wszedł $z$ nia w ścisłe stosunki, w wyniku których urodziła ona 2 marca 1828 r. syna, któremu na chrzcie świętym nadano imię Józef $z$ nazwiskiem matki, bez podania danych ojca. Dwa lata po urodzeniu syna zawarł ślub $z$ jego matką. Nie chcac własnemu dziecku „czynić krzywdy”, przyznał, że jest ono jego synem, które jak swoje wychował i pragnie, aby odtąd nosił jego nazwisko ${ }^{30}$.

W badanych przypadkach nie wystapiła sytuacja, w której osobą legalizującą dziecko był konkubent matki ${ }^{31}$.

27 Zawarli małżeństwo 11 I 1835 r. w Moszczenicy. Por. APŁ, USC Moszczenica, sygn. 39, Akt ślubu nr 1 z 1835 r.

28 AACz, Księgi Metrykalne, KM 45, Akt ślubu nr 36 z 1856 r.

${ }^{29}$ APPT, SPOR, sygn. 42, karty bez paginacji.

30 Ibidem, k. 12.

${ }^{31}$ Czasem przyznawal się do ojcostwa w samym akcie urodzenia dziecka. Por. P. Szkutnik, Nieślubne dzieci $w$ parafii Szadek $w$ okresie Księstwa Warszawskiego, „Przegląd Nauk Historycznych” 2013, R. XII, nr 2, s. 240-241. 
Wykres 2

Wiek matek

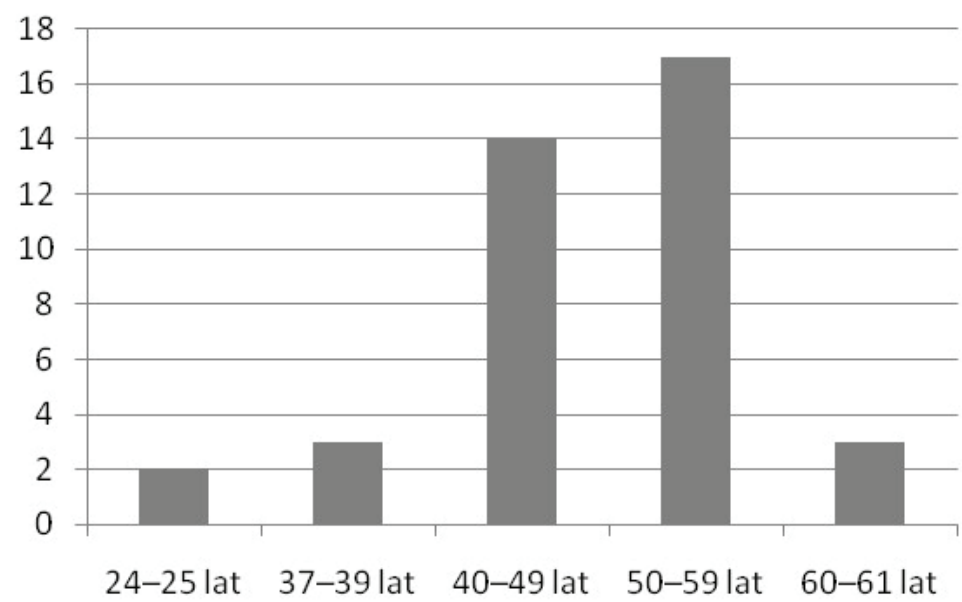

Źródło: Opracowanie własne na podstawie: Archiwum Państwowe w Piotrkowie Trybunalskim, Sąd Pokoju Okręgu Radomszczańskiego, sygn. 42.

\section{Wiek rodziców}

Ustalono wiek 40 spośród 49 rodziców uznających dzieci32. Legalizujacy mieli od 20 do 61 lat. Wśród 41 matek wiek znany jest dla $37 \mathrm{z}$ nich. Sa to kobiety liczace od 25 do 61 lat (średnio 48,7 lat). $\mathrm{W}$ tej grupie występuje tylko jedna młoda matka - Urszula de domo Krzymińska Stempniewska, mająca 25 lat. Dominuja matki w średnim wieku: 37-59 lat, których było 33 (89,2\%). Wynikało to $z$ faktu, że decydowały się na legalizację dziecka dopiero wówczas, gdy osiagnęło ono dojrzałość. W starszym wieku ${ }^{33}$ znajdowały się tylko trzy kobiety: Józefa $1^{\circ}$ voto Brulikowska $2^{\circ}$ voto Świerczyńska w wieku 61 lat, Ewa de domo Dobrowolska Glanek liczaca 60 lat i Dorota Masiarek liczaca 60 lat (por. wykres 2).

Spośród ośmiu ojców znany jest wiek dla trzech należących do różnych grup wiekowych. Byli nimi: liczący 20 lat Kazimierz

${ }^{32}$ Uzupełniono go częściowo na podstawie akt stanu cywilnego.

${ }^{33}$ Umowna granicę wieku starczego przyjmuje się na 60 lat. Por. A. Zielińska, Przemiany struktur demograficznych $w$ Toruniu $w$ XIX $i$ na poczatku XX wieku, Toruń 2012, s. 290. 
Woyciechowski, 46 lat Tadeusz Rybkowski, 60 lat Wojciech Strzelczyk (średnia ich wieku wynosi zatem 42 lata).

W czterech protokołach wspomina się o starości, argumentując w ten sposób konieczność pomocy ze strony dziecka ${ }^{34}$. Powołują się na ten powód kobiety w wieku 61 i 52 lat oraz - co zdumiewające - w wieku 37 lat. Zapis ten być może stanowił jedna ze standardowych formuł mających dowieść bliskich związków dziecka $z$ rodzicem i konieczności sprawowania nad nim opieki oraz pomocy w utrzymaniu. Wspomniana mężatka Józefa Świerczyńska z drugiego związku małżeńskiego miała tylko chorowita córkę. Zeznając 25 lipca 1848 r., podkreśliła odnośnie do nieślubnego syna, że „w nim jedyną podporę już w podeszłym swym wieku i męża mego do końca życia swego uważam"35. W świetle protokołów najstarszą matka legalizujacca dziecko miała być Apolonia z Naciów, liczaca w 1870 r. 68 lat. Przeprawiany na protokole wiek matki okazał się jednak błędny. W akcie urodzenia syna z 23 lipca 1848 r. podano, że miała 30 lat $^{36}$, co oznacza, że urodziła się w 1818 r., zatem w 1870 r. miała jedynie 52 lata.

Wykres 3

Wyznanie

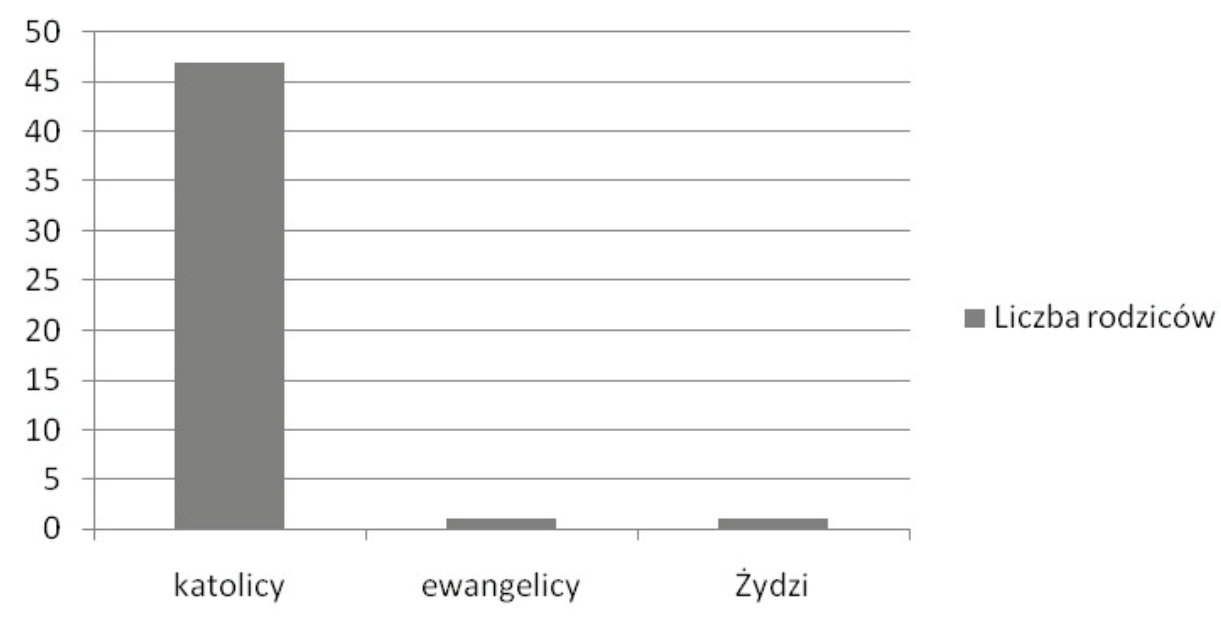

Źródło: Opracowanie własne na podstawie: Archiwum Państwowe w Piotrkowie Trybunalskim, Sąd Pokoju Okręgu Radomszczańskiego, sygn. 42.

${ }^{34}$ APPT, SPOR, sygn. 42, k. 9.

${ }^{35}$ Ibidem, k. 1-2.

${ }^{36}$ APŁ, USC Dabrowa, sygn. 33, Akt urodzenia nr 24 z 1848 r. 


\section{Wyznanie oraz pochodzenie spoleczne i terytorialne rodziców}

Na ogółem 49 legalizujących większość (47), tj. 95,9\%, stanowią katolicy, ponadto wystapiła jedna Żydówka i jedna ewangeliczka (por. wykres 3). Spośród uznających stan społeczny ustalono dla 25 matek i czterech ojców ${ }^{37}$. W większości (20), tj. 80\%, były to kobiety wywodzące się $z$ niższych warstw społeczeństwa bądź je stanowiące (por. wykres 4), czyli chłopki (6) określane jako pracowita, włościanka, córka rataja, rolnika, gospodarza; ponadto kobiety pracujace jako wyrobnice (11) oraz służące (3). Wśród nich była urodzona 20 maja 1820 r. Magdalena, córka Mateusza Olszowica, liczacego wówczas 35 lat gospodarza we wsi Wola Wydrzyna, i Petronelli Osińskiej mającej 25 lat ${ }^{38}$. Magdalena Olszowiczówna 27 stycznia 1849 r., w wieku 28 lat, urodziła we wsi Wola Wydrzyna w gminie Sulmierzyce syna Franciszka ${ }^{39}$. Gdy miała 49 lat, 2 lipca 1869 r., jako niezamężna wyrobnica uznała go za syna ${ }^{40}$.

Spośród omawianych matek wyróżnia się pięć pozostałych, $\mathrm{w}$ tym cztery jako szlachcianki ze spauperyzowanych rodów. Była nia pracująca jako gospodyni we dworze Ludwika Anastazja Wolska. Urodziła się 15 kwietnia 1829 r. w mieście Rozprza jako córka „leśnego", a jej rodzicami chrzestnymi byli miejscowy proboszcz i burmistrzowa ${ }^{41}$. Rodzice Ludwiki Anastazji: „urodzony” Jan Stanisław Feliks Wolski, ekonom we dworze, i „urodzona” Julianna Małgorzata Manikoska, „w obowiązku służby za pannę w dworze”, pobrali się 30 stycznia 1820 r. w Dobryszycach ${ }^{42}$.

Samodzielną działalność usługową prowadziła utrzymująca bufet na stacji kolei żelaznej w Radomsku Tekla $z$ Drużyckich $1^{\circ}$ voto Mirecka, która 15 kwietnia 1856 r. w Radomsku wyszła za Jana Lewińskiego, dozorcę przy kolei żelaznej ${ }^{43}$. Tekla była córka ekonoma Marcina Drużyckiego, szlachcica, oraz Marianny Małeckiej, pochodzacej ze stanu miejskiego ${ }^{44}$.

37 Posiłkowano się częściowo aktami urodzenia dzieci i ślubu rodziców.

38 AACz, Księgi Metrykalne, sygn. KM 1703, Akt urodzenia nr 64 z 1820 r.

39 AACz, Księgi Metrykalne, sygn. KM 1713, Akt urodzenia nr 15 z 1849 r.

40 APPT, SPOR, sygn. 42, karty bez paginacji.

41 APŁ, USC Rozprza, sygn. 47, Akt urodzenia nr 59 z 1829 r.

${ }^{42} \mathrm{AAC} z$, Księgi Metrykalne, sygn. KM 1318, Akt ślubu nr 2 z 1820 r.

$43 \mathrm{AACz}$, Księgi Metrykalne, sygn. KM 45, Akt ślubu nr 36 z 1856 r.

${ }^{44}$ APŁ, USC Krzepczów, sygn. 3, Akt urodzenia nr 14 z 1811 r. 
Magdalenę $z$ Dziatkiewiczów, pracującą w służbie we wsi Zuchowice, można zaliczyć do stanu miejskiego. W akcie swego ślubu z 17 czerwca 1861 r. we wsi Gorzkowice zawartym z ekonomem Stanisławem Radeckim ${ }^{45}$ została określona jako córka właścicieli we wsi Folwarki Miejskie ${ }^{46}$ (przedmieście należące do miasta Radomska), osiadłego na gospodarstwie Wincentego Dziatkiewicza i Katarzyny z Grzywaczów ${ }^{47}$.

Pochodzenie/zawód matek

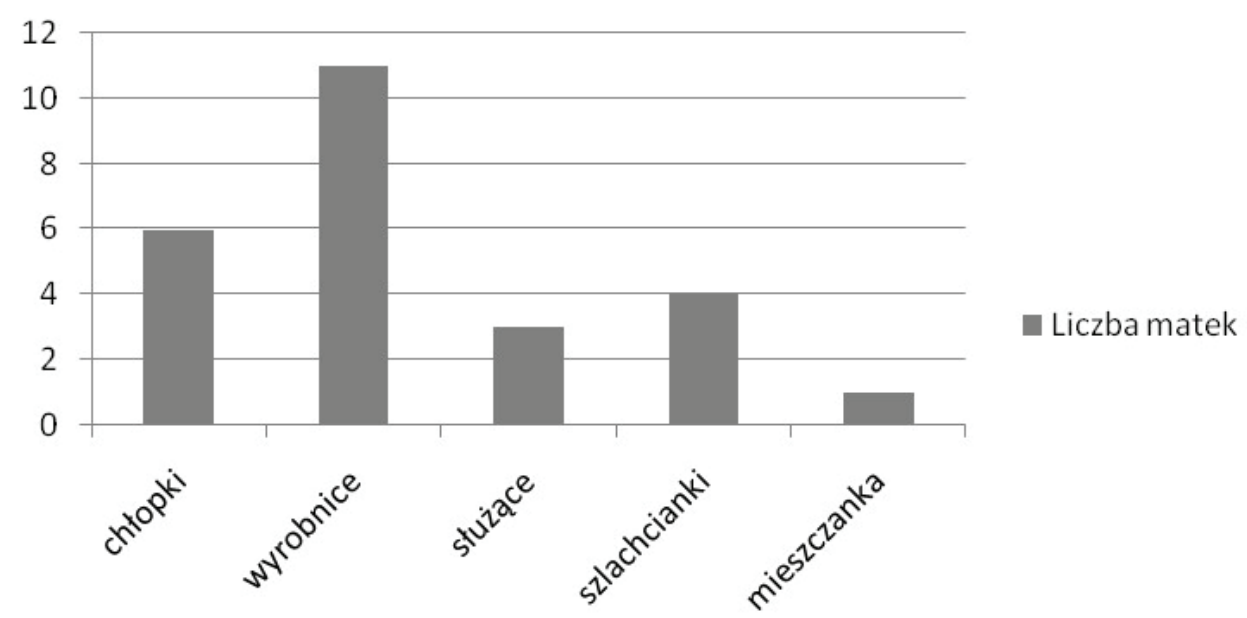

Źródło: Opracowanie własne na podstawie: Archiwum Państwowe w Piotrkowie Trybunalskim, Sąd Pokoju Okręgu Radomszczańskiego, sygn. 42.

Określono zawód czterech ojców uznających dziecko. Wśród nich był Grzegorz Gęsikowski, karbowy (nadzorca chłopów pracujących w folwarku), zamieszkały w Stanisławowie $z$ żona - Regina z Stymalów. Para zeznała w sądzie 21 czerwca 1849 r., że poznała się 21 lat wcześniej i weszła w bardzo bliskie stosunki, wskutek których 3 marca 1828 r. urodził się ich syn Kazimierz. Dopiero 27 lutego 1832 r. zawarli ze soba ślub ${ }^{48}$.

${ }^{45}$ APŁ, USC Gorzkowice, sygn. 58, Akt ślubu nr 15 z 1861 r.

${ }^{46}$ Gdzie się urodziła 28 V 1833 r. Por. AACz, Księgi Metrykalne, sygn. KM 54, Akt urodzenia nr 175 z 1833 r.

47 AACz, Księgi Metrykalne, sygn. KM 23, Akt urodzenia nr 376 z 1825 r.

${ }^{48}$ APPT, SPOR, sygn. 42, k. 6-6v. 
Pozostali ojcowie to wspomniany T. Rybkowski, ogrodnik, zamieszkały we wsi Sokola Góra, który był synem mieszczan z Jędrzejowa. Poślubił 23 maja 1830 r. w parafii Stanowiska „szlachetna” Barbarę Wrześniakowska, matkę dziecka ${ }^{49}$. Wśród ojców wystąpił ponadto kucharz, który później osiadł na gospodarstwie, oraz dymisjonowany żołnierz wojsk carskich.

Rodzice zgłaszający wyżej wymienione legalizacje mieszkali na obszarze okręgu omawianego sądu pokoju. Byli to w większości, 47 osób, tj. 95,9\%, mieszkańcy wsi. Tylko dwie matki mieszkały w mieście, wspomniana Żydówka w Pajęcznie oraz bufetowa w Noworadomsku.

\section{Podsumowanie}

Analizie poddano 43 protokoły legalizacji, które zostały zarejestrowane w Sądzie Pokoju Okręgu Radomszczańskiego w latach 1845-1874. Legalizacji łącznie dokonało 49 rodziców. Najczęściej przeprowadzał ją samodzielnie jeden $z$ rodziców (35 matek i 2 ojców), rzadziej pary (6). Matki niezamężne (25 na łącznie 41) częściej decydowały się na legalizację dziecka naturalnego, bo nie wiązało się to ze zgodą czy asystencją męża. Spośród 11 panien tylko jedna podała nazwisko ojca dziecka. Wśród 14 wdów większość (10) legalizowała dziecko niepochodzące ze związku z mężem, a $z$ innym mężczyzna, natomiast pozostałe (4) legalizowały dziecko ze związku ze zmarłym mężem. Wśród 16 mężatek dziewięć zabiegało o legalizację dziecka pochodzacego $z$ poprzedniego związku, a siedem $z$ aktualnego.

Spośród 37 matek ze znanym wiekiem większość (33) liczyła 37-59 lat, co wynikało z późnej decyzji o legalizacji dziecka (syna) znajdującego się wieku poborowym. Legalizującymi byli zwykle katolicy. Wyjatek stanowi jedna Żydówka oraz jedna ewangeliczka. Identyczne proporcje występuja w przypadku miejsca zamieszkania rodziców pochodzacych w większości ze wsi, a jedynie dwoje $z$ miasta. W grupie matek, dla których ustalono stan społeczny (25), większość (20) wywodziła się z niższych warstw społecznych, tj. stanu chłopskiego. Pozostałe matki to zubożałe szlachcianki oraz mieszczanka. Czterej ojcowie znani z profesji: to karbowy, kucharz, ogrodnik i żołnierz. Reasumując, legalizującymi dzieci były przede wszystkim matki w średnim wieku, pochodzące $z$ niższych warstw społecznych, zamieszkałe na wsi.

49 Ibidem, k. 13-14. 


\section{Bibliografia}

\section{Ż́ódea ARChIWALNe}

Archiwum Archidiecezji Częstochowskiej [AACz]

Księgi metrykalne, sygn. KM 23, KM 45, KM 54, KM 1318, KM 1319, KM 1703, KM 1713, KM 4493.

Archiwum Państwowe w Łodzi [APŁ]

Urząd Stanu Cywilnego Bęczkowice, sygn. 37 i 40.

Urzad Stanu Cywilnego Dabrowa, sygn. 33.

Urząd Stanu Cywilnego Dobryszyce, sygn. 10, 33 i 34.

Urzad Stanu Cywilnego Gorzkowice, sygn. 58.

Urząd Stanu Cywilnego Krzepczów, sygn. 3.

Urzad Stanu Cywilnego Moszczenica, sygn. 39.

Urząd Stanu Cywilnego Rozprza, sygn. 47.

Archiwum Państwowe w Piotrkowie Trybunalskim [APPT]

Sąd Pokoju Okręgu Radomszczańskiego [SPOR], sygn. 42.

\section{ŹRÓDEA DRUKOWANE}

Dziennik Praw Królestwa Polskiego, t. X, Warszawa 1825.

Dzierożyński D., Instrukcya dokładna o urzędnikach i aktach stanu cywilnego, Warszawa 1813.

Kodex Napoleona z przypisami. Xiag trzy, Warszawa 1810.

Prawo cywilne obowiazujace $w$ Królestwie Polskim, t. I, wyd. S. Zawadzki, Warszawa 1860.

\section{OpRacowania}

Bandurka M., Zmiany administracyjne i terytorialne ziem województwa łódzkiego w XIX I XX wieku, Łódź 1995.

Machut-Kowalczyk J., Panny, mężatki i wdowy przed sadem pokoju: prawo a praktyka w Królestwie Polskim na przykładzie akt sąów pokoju okręgu łęczyckiego, zgierskiego i łódzkiego, „Studia z Dziejów Państwa i Prawa Polskiego” 2013, t. XVI, s. 201-214.

Szkutnik P., Legalizacje dzieci $w$ świetle akt Sadu Pokoju Okręgu Radomszczańskiego w latach 1845-1874, „Przeszłość Demograficzna Polski” 2019, t. XL, s. 197-214.

Szkutnik P., Nieślubne dzieci $w$ parafii Szadek $w$ okresie Księstwa Warszawskiego, „Przeglad Nauk Historycznych” 2013, R. XII, nr 2, s. 237-252.

Szkutnik P., Owoce nieformalnych zwiazków. Egzemplifikacje na podstawie akt stanu cywilnego parafii Szadek z poczatku XIX w., [w:] Antropologia miłości, t. VI (Miłość sprzedajna), red. B. Płonka-Syroka, K. Marchel, A. Syroka, Wrocław 2014, s. 193-203. 
Teleszewska M., Status prawny dzieci nieślubnych na ziemiach polskich $w$ dobie zaborów w świetle Kodeksu Cywilnego Napoleona, „Czasopismo Prawno-Historyczne" 2014, t. LXVI, z. 1, s. 383-391.

Zielińska A., Przemiany struktur demograficznych $w$ Toruniu $w$ XIX i na początku XX wieku, Toruń 2012.

Piotr SzKuTnik

UNIVERSITY OF LODZ

\section{Parents legitimatising children in the light of records of the Magistrate's Courts of the Radomsko district in the years of 1845-1874}

D rotocols of legalisation created in the Peace Court of the Radomsko District in the years 1845-1874 allowed for analyses of persons deciding on this legal act. Based on 43 documents 49 persons legitimatising their children were established. They included 41 mothers and 8 fathers. Couples performed legitimatisation in 6 cases, only fathers in 2 cases, and mothers in 35 cases. The mothers had different marital status. Among them 11 were unmarried women, 16 were married and 14 were widows. Most often, therefore, they were mothers who were not married.

The age of 40 parents recognising children was determined. The legitimatising parents were from 20 to 61 years old. The age is known for 37 of the 41 mothers. They were women aged 25 to 61 (48.7 years old on average). Middle-aged mothers aged 37-59 dominated (33 cases, i.e. 89.2\%). This was due to the fact that they decided to legitimatise their children only after they reached maturity. Out of the total of 49 legalising persons, the majority (47), i.e. $95.9 \%$, were Catholics; there was also one Jewish woman and one member of the Evangelical Church.

The social status of 25 mothers and 4 fathers was determined from amongst those who legalised their children. In most cases (20), i.e. 80\%, they were women representing lower classes of society. Women of a peasant origin (6) were referred to as hard-working, peasants, daughters of a free peasant, farmer or landowner. There were also women working as charwomen (11) and as servants (3). The majority of the legitimatising persons were inhabitants of rural areas (47), i.e. 95.9\%; only two legitimatising persons came from a town or a city.

Most of the people legitimatising children were middle-aged mothers representing lower social classes and living in rural areas.

Keywords: legitimatisation of children, illegitimate children, military service, court of peace, Radomsko district, $19^{\text {th }}$ century. 